\title{
Molecular markers useful to discriminate Coffea arabica cultivars with high genetic similarity
}

\author{
Tiago Vieira Sousa - Eveline Teixeira Caixeta - Emilly Ruas Alkimim • \\ Antonio Carlos Baião de Oliveira • Antonio Alves Pereira · Laércio Zambolim • \\ Ney Sussumu Sakiyama
}

Received: 8 December 2016/ Accepted: 26 February 2017

(C) Springer Science+Business Media Dordrecht 2017

\begin{abstract}
New cultivars are released every year to meet market demands. However, in species with a narrow genetic base, such as Coffea arabica, the cultivars are closely related and phenotypically similar. This hinders the accurate discrimination of genotypes using morphological descriptors in distinctness, uniformity, and stability (DUS) testing, which is required for the registration and protection of new cultivars. In this sense, molecular markers are an auxiliary tool for accurate and precise discrimination of cultivars. This study aimed to verify the informative capacity and effectiveness of a molecular marker set to discriminate among $C$. arabica varieties, create a database of DNA profiles and allele frequencies, analyze the genetic diversity in this collection, and explore genetic kinships. Thirty-four C. arabica cultivars/progenies, which belong to the Brazilian
\end{abstract}

T. V. Sousa - E. R. Alkimim

Instituto de Biotecnologia Aplicada à Agropecuária (BIOAGRO), BioCafé, Universidade Federal de Viçosa, Viçosa-MG 36570-000, Brazil

\section{E. T. Caixeta ( $\square)$}

Empresa Brasileira de Pesquisa Agropecuária - Embrapa Café, BIOAGRO, BioCafé, Universidade Federal de

Viçosa, Viçosa-MG 36570-000, Brazil

e-mail: eveline.caixeta@embrapa.br

A. C. B. de Oliveira

Embrapa Café, Empresa de Pesquisa Agropecuária de Minas Gerais, Viçosa-MG 36570-000, Brazil
Cultivar Trial, were analyzed using 31 microsatellite markers. Markers with weak bands were removed, and of the remaining, $74.07 \%$ were polymorphic and revealed 47 alleles. The obtained molecular profiles revealed segregation between and within cultivars/ progenies, and genetic variability was observed between all the cultivars/progenies. Sixteen markers were selected for dendrogram construction and for fingerprinting analysis of the cultivars. The ability of these markers to detect varietal mixture and analyze diversity between and within cultivars was also discussed in detail. The results demonstrated the effectiveness of markers in distinguishing related genotypes from those with similar phenotypic traits. This biotechnological tool will assist breeders in DUS testing of cultivars. 
Keywords Fingerprinting - Molecular profiling · Genetic diversity $\cdot$ Cultivar identification · Protection of plant cultivars $\cdot$ Cultivars register $\cdot$ SSR marker

\section{Introduction}

Plant breeding programs aim at more productive and adapted cultivars. However, with the large number of cultivars that have already been released, identification and characterization of these materials, based solely on morphological traits, is not easy (Ercisli et al. 2008; Lanteri et al. 2012; Korir et al. 2013).

For a cultivar to be released, it must be registered, and to ensure the intellectual property rights to the breeder, this cultivar needs to be protected. Registration of cultivars facilitates production, processing, and marketing of seeds and seedlings (Santos et al. 2012). In addition, protection of plant variety enables public and private research companies to be benefited from the royalties received from the rights on the cultivars they develop (Carvalho et al. 2009).

Both registration and protection of plant cultivars require distinctness, uniformity, and stability (DUS). Distinctness, uniformity, and stability testing, which is carried out by the evaluation of morphological descriptors recommended for each species. This approach is subjective, time consuming, and expensive (Korir et al. 2013). As an auxiliary alternative, the use of molecular descriptors has been widely discussed in the Working Group on Biochemical and Molecular Techniques (BMT) and DNA Profiling of the International Union for The Protection of New Varieties of Plants (UPOV 2010) in particular, and it is recommended for the identification, registration, and protection of new cultivars (Wang and Chuang 2013; Chen et al. 2016). Molecular markers aid breeders in DUS testing of cultivars with a narrow genetic base (Ferreira et al. 2016), and in the case of Coffea arabica, this strategy is especially useful (Ferrão et al. 2015).

Similar to other species, new C. arabica cultivars are released every year to meet the demand of the world market. Cultivars with much higher yield potential than those initially introduced in Brazil were developed by genetic breeding programs (Carvalho 1981). In Brazil alone, to date, 131 C. arabica cultivars have been registered on the National Register of Cultivars (NRC) of the Ministry of Agriculture, Livestock and Supply (MAPA) (Brasil 2017a). However, these cultivars were obtained from a few parents, resulting in low variability (Setotaw et al. 2013). This hinders the accurate and precise discrimination of genotypes by morphological descriptors (Lanteri et al. 2012).

Other factors have also contributed to the reduction in genetic variability of coffee plants and have favored the increase in related genotypes. Thus, the spread of C. arabica globally and the history of the introduction of this species in Brazil should be mentioned. All coffee plants originated from a limited number of seeds collected from Ethiopia, its center of origin, diversity, and dispersion. It is noteworthy that the genetic base of most coffee cultivars available in the world is from a single progeny cultivated in Europe (Silvestrini et al. 2007). In Brazil, few seedlings and seeds from French Guiana were introduced in Belem, Pará state. These materials are the genetic base of the plants of coffee plantations in Brazil. Furthermore, autogamy is a crucial factor, through which approximately $90 \%$ of the flowers are fertilized by the plant's own pollen (Anthony et al. 2002). In addition, selection carried out by the breeder for the best traits can lead to unconscious selection of related genotypes. Several studies have demonstrated the low genetic variability of commercially planted $C$. arabica cultivars (Lashermes et al. 2000; Anthony et al. 2001; Maluf et al. 2005; Cubry et al. 2008; Lashermes et al. 2011; Setotaw et al. 2013; Motta et al. 2014; Pestana et al. 2015).

Thus, the development of a molecular marker set to establish the molecular pattern of each cultivar (fingerprinting) is extremely important to breeding programs. This cultivar discrimination must be fast, accurate, and precise (Collard et al. 2005; Le et al. 2016). Molecular markers have been increasingly used in recent times and is also important for the continuity of breeding programs and for the guarantee of the intellectual property of the final product of genetic selection (Ercisli et al. 2011; Rauscher and Simko 2013; Scarano et al. 2015).

Among the several types of molecular markers, microsatellites (SSR) are most commonly used in genetic diversity and fingerprinting studies. Besides being locus specific, it possess several advantages, including high degree of polymorphism, repeatability, reproducibility, codominance, and multiallelism 
(Banerjee et al. 2012; Kaur et al. 2015). The advantages of molecular markers have also been highlighted in various studies on coffee plants (Diola et al. 2011; Missio et al. 2011; Motta et al. 2014; Ferrão et al. 2015; Pestana et al. 2015).

Thus, this study aimed to: (a) verify the informative capacity and effectiveness of molecular markers to discriminate amongst coffee varieties (b) create a database of DNA profiles and allele frequencies (c) analyze the genetic diversity existing in this collection, and (d) explore genetic kinships.

\section{Materials and methods}

\section{Genetic material}

A total of 34 C. arabica genotypes of were used in this study (Table 1); these included cultivars carrying genes that confer resistance to rust, the most important disease in coffee plants. This genetic material is maintained at the experimental area of the Department of Plant Pathology of the Universidade Federal de Viçosa. These plants, which belong to the Brazilian Cultivar Trial, were selected due to the difficulty in their discrimination based on morphological traits and commercial importance. The trial has been carried out in the main coffee-producing regions of Brazil.

The genotypes evaluated were composed of 26 cultivars, five elite progenies resistant to coffee leaf rust, and three susceptible cultivars. From the three susceptible cultivars, two belonged to the group Catuaí and one belonged to the group Bourbon. Catuaí is the most planted group of commercial cultivar in Brazil (Fernandes et al. 2012), while the group Bourbon is recognized for its excellent cup quality worldwide; this quality is a highly valued trait in special coffee markets (Ferreira et al. 2013).

Currently, of the 131 cultivars of $C$. arabica registered in the NRC of MAPA (Brasil 2017a), 14 cultivars are protected by the National Service of Plant Variety Protection (NSPVP) (Brasil 2017b). Out of these cultivars, seven (Araponga MG 1 [28], Catiguá MG 1 [24], Catiguá MG 2 [25], IPR 98 [18], Pau Brasil MG 1 [29], Sacramento MG 1 [27], and IAC 125 RN [14]) were evaluated in this study.

In each cultivar/progeny, six plants were analyzed, constituting a total of 204 genotypes. The occurrence of genetic variability per locus, between and within cultivars, was verified. The genetic variability within cultivars was evaluated by analyzing the six individuals that constituted each genetic material. Genetic variability between cultivars was evaluated in the same locus as follows: first, the alleles observed in the bulk data of individuals were analyzed and then the alleles observed per individual were analyzed.

\section{DNA extraction and SSR marker amplification}

In each selected genotype, healthy, fully expanded, young, and light green colored leaves were collected. The leaves were lyophilized and powdered. Genomic DNA was extracted using the method proposed by Diniz et al. (2005). DNA quality and quantity were evaluated using the NanoDrop 2000-Thermo Scientific spectrophotometer. The samples were standardized at $25 \mathrm{ng} \mu \mathrm{L}^{-1}$ and stored at $-20{ }^{\circ} \mathrm{C}$.

A total of 31 pairs of microsatellite primers were used (Online Resource 1). PCR amplification was carried out as follows: $50 \eta \mathrm{g}$ DNA, $1 \mathrm{U}$ Taq polymerase, $1 \mathrm{X}$ enzyme buffer, $1.0 \mathrm{mM} \mathrm{MgCl}_{2}$, $150 \mu \mathrm{M}$ of each dNTP, and $0.1 \mu \mathrm{M}$ of each primer, completing the total volume of $20 \mu \mathrm{L}$ with milli-Q sterile water. The reactions were carried out on PTC200 (MJ Research) and Veriti (Applied Biosystems) Thermal Cyclers. After the initial denaturation at $94{ }^{\circ} \mathrm{C}$ for $2 \mathrm{~min}, 10$ touchdown PCR cycles were carried out at $94{ }^{\circ} \mathrm{C}$ for $30 \mathrm{~s}$; with decreasing annealing temperature of $1{ }^{\circ} \mathrm{C}$ for every cycle (66 to $57^{\circ} \mathrm{C}$ ) for $30 \mathrm{~s}$; and extension at $72{ }^{\circ} \mathrm{C}$ for $30 \mathrm{~s}$, followed by 30 cycles of denaturation at $94{ }^{\circ} \mathrm{C}$, annealing at $57^{\circ} \mathrm{C}$, and extension at $72{ }^{\circ} \mathrm{C}$ for $30 \mathrm{~s}$ at each stage. Final extension was carried out at $72{ }^{\circ} \mathrm{C}$ for $8 \mathrm{~min}$. The resulting products of the PCR reaction were separated by $6 \%$ polyacrylamide denaturing gel electrophoresis and visualized by silver nitrate staining (Brito et al. 2010).

\section{Statistical analysis}

The fragments amplified by SSR markers (codominant) were coded according to the observed genotype and software requirements. Thus, for example, for the locus with four alleles, individuals were assigned 11, 22,33 , and 44 codes for the homozygote genotype, or $12,13,14,23,24$, and 34 for heterozygote genotypes. The distance matrix was generated by the arithmetic complement of the unweighted index (Cruz et al. 
Table 1 Coffee trees analyzed with molecular markers

\begin{tabular}{|c|c|c|c|c|c|c|}
\hline No. & Cultivar or Progeny & Origin & $\begin{array}{l}\mathrm{RNC}^{\mathrm{a}} \\
\text { number }\end{array}$ & $\begin{array}{l}\text { Rust resistance } \\
\text { reaction }\end{array}$ & $\begin{array}{l}\text { Resistance } \\
\text { source }^{\mathrm{b}}\end{array}$ & Observations \\
\hline 1 & $\begin{array}{l}\text { Catuaí Vermelho IAC } \\
144\end{array}$ & IAC & 02934 & $S^{c}$ & - & \\
\hline 2 & $\begin{array}{l}\text { Catuaí Vermelho IAC } \\
15\end{array}$ & IAC & 02927 & $\mathrm{~S}$ & - & \\
\hline 3 & $\begin{array}{l}\text { Bourbon Amarelo } \\
\text { UFV } 535\end{array}$ & UFV & - & $\mathrm{S}$ & - & $\begin{array}{l}\text { Cultivar with cup quality } \\
\text { standard }\end{array}$ \\
\hline 4 & Catucaí Amarelo 2SL & $\begin{array}{l}\text { MAPA/Fundação } \\
\text { Procafé }\end{array}$ & 04915 & $\mathrm{MR}^{\mathrm{d}}$ & Icatu & \\
\hline 5 & Catucaiam 24137 & $\begin{array}{l}\text { MAPA/Fundação } \\
\text { Procafé }\end{array}$ & 28888 & MR & Icatu & \\
\hline 6 & Catucaiam 2015479 & $\begin{array}{l}\text { MAPA/Fundação } \\
\text { Procafé }\end{array}$ & 28885 & MR & Icatu & \\
\hline 7 & Catucaí 785-15 & $\begin{array}{l}\text { MAPA/Fundação } \\
\text { Procafé }\end{array}$ & 04996 & MR & Icatu & $\begin{array}{l}\text { Resistance to the nematode } \\
\text { M. exigua }\end{array}$ \\
\hline 8 & $\begin{array}{l}\text { Catucaí Vermelho } \\
20 / 15\end{array}$ & $\begin{array}{l}\text { MAPA/Fundação } \\
\text { Procafé }\end{array}$ & 04910 & MR & Icatu & \\
\hline 9 & Sabiá tardio & $\begin{array}{l}\text { MAPA/Fundação } \\
\text { Procafé }\end{array}$ & 04992 & MR & CIFC 832/1 & \\
\hline 10 & IBC-Palma-2 & $\begin{array}{l}\text { MAPA/Fundação } \\
\text { Procafé }\end{array}$ & 04998 & MR & CIFC 832/1 & \\
\hline 11 & Acauã & $\begin{array}{l}\text { MAPA/Fundação } \\
\text { Procafé }\end{array}$ & 04995 & $\mathrm{R}^{\mathrm{e}}$ & CIFC $832 / 2$ & \\
\hline 12 & $\begin{array}{l}\text { Tupi Amarelo IAC } \\
5162\end{array}$ & IAC & - & $\mathrm{R}$ & CIFC $832 / 2$ & $\begin{array}{l}\text { Elite progeny of the IAC } \\
\text { breeding program }\end{array}$ \\
\hline 13 & Tupi IAC 1669-33 & $\mathrm{IAC}$ & 02957 & $\mathrm{R}$ & CIFC $832 / 2$ & \\
\hline 14 & IAC $125 \mathrm{RN}$ & IAC & 28587 & $\mathrm{R}$ & CIFC 832/2 & $\begin{array}{l}\text { Cultivar protected by the } \\
\text { NSPVP }^{\mathrm{f}} \text { and resistance to } \\
\text { the nematode } M \text {. exigua }\end{array}$ \\
\hline 15 & Obatã IAC 1669-20 & $\mathrm{IAC}$ & 02956 & $\mathrm{R}$ & CIFC 832/2 & \\
\hline 16 & $\begin{array}{l}\text { Obatã Amarelo IAC } \\
4932\end{array}$ & IAC & - & MR & CIFC $832 / 2$ & $\begin{array}{l}\text { Elite progeny of the IAC } \\
\text { breeding program }\end{array}$ \\
\hline 17 & Iapar 59 & IAPAR & 02324 & $\mathrm{R}$ & CIFC 832/2 & \\
\hline 18 & IPR 98 & IAPAR & 09950 & $\mathrm{R}$ & CIFC 832/2 & $\begin{array}{l}\text { Cultivar protected by the } \\
\text { NSPVP }^{\mathrm{f}}\end{array}$ \\
\hline 19 & IPR 99 & IAPAR & 09949 & MR & CIFC $832 / 2$ & \\
\hline 20 & IPR 100 & IAPAR & 09948 & MR & BA-10 & \\
\hline 21 & IPR 103 & IAPAR & 09945 & MR & Icatu & $\begin{array}{l}\text { Resistance to the } \\
\text { nematodes } M \text {. } \\
\text { paranaensis and } M \text {. } \\
\text { incognita }\end{array}$ \\
\hline 22 & IPR 104 & IAPAR & 09944 & $\mathrm{R}$ & CIFC $832 / 2$ & \\
\hline 23 & Oeiras MG 6851 & EPAMIG/UFV & 04755 & MR & CIFC 832/1 & \\
\hline 24 & Catiguá MG1 & EPAMIG/UFV & 18632 & $\mathrm{R}$ & UFV440-10 & $\begin{array}{l}\text { Cultivar protected by the } \\
\text { NSPVP }^{f}\end{array}$ \\
\hline 25 & Catiguá MG2 & EPAMIG/UFV & 18633 & $\mathrm{R}$ & UFV440-10 & $\begin{array}{l}\text { Cultivar protected by the } \\
\text { NSPVP }^{f}\end{array}$ \\
\hline 26 & MGS Catiguá 3 & EPAMIG/UFV & 22098 & $\mathrm{R}$ & UFV440-10 & $\begin{array}{l}\text { Resistance to nematode } M \text {. } \\
\text { exigua and Coffea Berry } \\
\text { Disease }\end{array}$ \\
\hline
\end{tabular}


Table 1 continued

\begin{tabular}{|c|c|c|c|c|c|c|}
\hline No. & Cultivar or Progeny & Origin & $\begin{array}{l}\mathrm{RNC}^{\mathrm{a}} \\
\text { number }\end{array}$ & $\begin{array}{l}\text { Rust resistance } \\
\text { reaction }\end{array}$ & $\begin{array}{l}\text { Resistance } \\
\text { source }^{\mathrm{b}}\end{array}$ & Observations \\
\hline 27 & Sacramento MG1 & EPAMIG/UFV & 18631 & $\mathrm{R}$ & UFV438-52 & $\begin{array}{l}\text { Cultivar protected by the } \\
\text { NSPVP }^{f}\end{array}$ \\
\hline 28 & Araponga MG1 & EPAMIG/UFV & 18635 & $\mathrm{R}$ & UFV446-08 & $\begin{array}{l}\text { Cultivar protected by the } \\
\text { NSPVP }^{f}\end{array}$ \\
\hline 29 & Pau Brasil MG1 & EPAMIG/UFV & 18634 & $\mathrm{R}$ & UFV442-34 & $\begin{array}{l}\text { Cultivar protected by the } \\
\text { NSPVP }^{f}\end{array}$ \\
\hline 30 & Paraíso MG H 419-1 & EPAMIG/UFV & 15981 & $\mathrm{R}$ & UFV445-46 & \\
\hline 31 & Н 419-3-3-7-16-4-1 & EPAMIG/UFV & - & $\mathrm{R}$ & UFV445-46 & $\begin{array}{l}\text { Elite progeny of the } \\
\text { Epamig/UFV breeding } \\
\text { program }\end{array}$ \\
\hline 32 & H 419-10-6-2-5-1 & EPAMIG/UFV & - & $\mathrm{R}$ & UFV445-46 & $\begin{array}{l}\text { Elite progeny of the } \\
\text { Epamig/UFV breeding } \\
\text { program }\end{array}$ \\
\hline 33 & H 419-10-6-2-10-1 & EPAMIG/UFV & - & $\mathrm{R}$ & UFV445-46 & $\begin{array}{l}\text { Elite progeny of the } \\
\text { Epamig/UFV breeding } \\
\text { program }\end{array}$ \\
\hline 34 & H 419-10-6-2-12-1 & EPAMIG/UFV & - & $\mathrm{R}$ & UFV445-46 & $\begin{array}{l}\text { Elite progeny of the } \\
\text { Epamig/UFV breeding } \\
\text { program }\end{array}$ \\
\hline \multicolumn{7}{|c|}{${ }^{a}$ Number of National Register of cultivars } \\
\hline \multicolumn{7}{|c|}{ b Source of rust resistance used for the development of the cultivar } \\
\hline \multicolumn{7}{|c|}{ c Susceptible } \\
\hline \multicolumn{7}{|c|}{${ }^{\mathrm{d}}$ Moderately resistant } \\
\hline \multicolumn{7}{|c|}{ e Resistante } \\
\hline
\end{tabular}

2011) implemented in the GENES software (Cruz 2013), and the node consistency dendrogram was generated using the MEGA7 software (Kumar et al. 2016).

Genetic distance can be estimated by the following equation

$D_{i i^{\prime}}=1-\left(\frac{1}{2 L} \sum_{j=1}^{L} C_{j}\right)$

where Dii' is the genetic distance between pairs of accessions $i$ and $i^{\prime}$; $L$ is the total number of loci studied; and $\mathrm{C}_{\mathrm{j}}$ is the number of common alleles between pairs of accessions $i$ and $i^{\prime}$.

A dendrogram was constructed, and two fingerprinting analysis were performed. The genotypes were analyzed separately; however, in the construction of the dendrogram and in the first fingerprinting analysis, the bulk of data of the six genotypes for each cultivar/ progeny was used. Thus, if the marker appeared in only one individual, it would be considered in the molecular profile of the cultivar. The second fingerprinting analysis was performed with individual data of the genotypes composed of each cultivar/progeny.

The dendrogram was constructed using the UPGMA clustering technique from the values of the distance matrix generated. A set of markers to be used in the discrimination of the cultivars/progenies evaluated were also defined, establishing the unique marker profiles for each cultivar (fingerprinting).

\section{Results}

Of the 31 pairs of microsatellite primers analyzed in the cultivars/progenies, four amplified weak bands and were therefore removed from the study. Of the remaining markers, 20 were polymorphic $(74.04 \%)$ and revealed 47 alleles. The number of alleles per 
locus ranged from two to four, with an average of 2.35 alleles.

Molecular profiles obtained using SSR markers presented segregation between and within cultivars/ progenies. Genetic variability was observed between all the cultivars/progenies studied. Online Resource 2 shows polymorphism within the cultivars Catiguá MG1 (24) and Sacramento MG1 (27) and polymorphism between the cultivars Catiguá MG2 (25) and Araponga MG1 (28) for CaEST-031 SSR marker. In this example, heterozygote individuals carrying alleles $\mathrm{A}^{1} \mathrm{~A}^{2}$ were encoded as 12 ; and homozygote individuals carrying only allele $\mathrm{A}^{1}$ and allele $\mathrm{A}^{2}$ were encoded as 11 and 22, respectively.

Of the 204 analyzed genotypes, four plants (IBC-Palma-2 [10] plant 07-B2-P2, Tupi IAC 1669-33 [13] plant 16-B3-P1, IAC 125 RN [14] plant 30-B2-P4, and Catuaí Vermelho IAC 15 [2] plant 32-B1-P6) showed different alleles in several loci compared to the molecular profile of its cultivar. These plants were removed and not included for further analyses.

Analysis of the 20 polymorphic markers showed that the number of polymorphic microsatellite loci among individuals within the cultivar/progeny ranged from 0 to 11 (Table 2). Eight cultivars/progenies showed no segregation among the six individuals which constitute them. On the other hand, in Catiguá MG1 (24) cultivar individuals, polymorphism was observed in 11 SSRs markers (55\%).
Although the number of polymorphic loci was the same for a few cultivars, variability was also found among them. Polymorphism in one locus (5\%) was observed for cultivars IAC 125 RN (14), MGS Catiguá 3 (26), IPR 99 (19), and IPR 100 (20). However, cultivar IAC $125 \mathrm{RN}$ (14) presented one segregating individual, cultivar MGS Catiguá 3 (26) presented two segregating individuals, and cultivars IPR 99 (19) and IPR 100 (20) presented segregation in three of the six individuals which constitute them.

Only the microsatellite polymorphic markers whose loci were diploid and codominant were considered for dendrogram construction and for the establishment of cultivar molecular profiles (fingerprinting). Thus, of the 20 polymorphic markers analyzed, 16 were selected and all subsequent analyses were performed using them. The markers CaEST-006, CaEST-040, CaEST-089, and SSRCa 52 were eliminated, since they amplified three or four alleles per individual.

From the set of 16 SSR markers, two showed a heterozygous molecular profile for most of the cultivars/progenies evaluated, although $C$. arabica is an autogamous species. CaEST030 revealed homozygous pattern only in the individuals of the cultivar IBC-Palma-2 (10), and CaEST-024 revealed only in tree cultivars Tupi Amarelo IAC 5162 (12), Tupi IAC 1669-33 (13), and IAC 125 RN (14).

The dendrogram, with $40 \%$ maximum dissimilarity observed at the last fusion level (0.41), showed 14

Table 2 Number of polymorphic loci within the cultivar/progeny analyzed by 20 polymorphic markers

\begin{tabular}{ll}
\hline $\begin{array}{l}\text { No. of polymorphic } \\
\text { loci }\end{array}$ & Cultivars/progenies \\
\hline 0 & $\begin{array}{l}\text { Catuaí Vermelho IAC 144, Catuaí Vermelho IAC 15, Bourbon Amarelo UFV535, Catucaí Vermelho 20/15, } \\
\text { Sabiá tardio, Obatã IAC 1669-20, IPR 103 e H 419-3-3-7-16-4-1 }\end{array}$ \\
1 & IAC 125 RN, IPR 99, IPR 100 e MGS Catiguá 3 \\
2 & Catucaí Amarelo 2SL, Catucaiam 24137, Catucaí 785-15, IBC-Palma-2, Acauã, Tupi IAC 1669-33, Obatã \\
3 & Amarelo 4932, Oeiras MG 6851, Araponga MG1 e H 419-10-6-2-10-1 \\
4 & Catucaiam 2015479 e Catiguá MG2 \\
5 & IPR 98 e H 419-10-6-2-12-14 \\
6 & Paraíso MG H 419-1 \\
7 & IPR 104 e Sacramento MG1 \\
8 & Tupi Amarelo IAC 5162 e Iapar 59 \\
9 & Pau Brasil MG1 \\
11 & H 419-10-6-2-5-1 \\
\hline
\end{tabular}


groups (Fig. 1). Three groups clustered two cultivars/ progenies: the first group comprised cultivars Iapar 59 (17) and IPR 104 (22), the second group consisted of cultivars Tupi IAC 1669-33 (13) and IAC $125 \mathrm{RN}$ (14), and the third group comprised $\mathrm{H}$ 419-10-6-2-101 (33) and $\mathrm{H}$ 419-10-6-2-12-1 (34). One group clustered three cultivars, namely Tupi Amarelo IAC 5162 (12), IPR 98 (18), and Pau Brasil MG1 (29). Nine cultivars/progeny, namely (IBC-Palma-2 [10], Acauã [11], IPR 99 [19], Catiguá MG1 [24], Catiguá MG2 [25], MGS Catiguá 3 [26], Sacramento MG1 [27], Paraíso MG H 419-1 [30], and H 419-10-6-2-5-1[32]) did not cluster with the group containing one cultivar.

The remaining cultivars were allocated to a single cluster. This cluster was divided into two sub-clusters, one consisting of the cultivars/progenies Catuaí Vermelho IAC 144 (1), Catuaí Vermelho IAC 15 (2), Bourbon Amarelo UFV535 (3), Catucaiam 2015479 (6), Sabiá tardio (9), Obatã IAC 1669-20 (15), Obatã Amarelo 4932 (16), Araponga MG1 (28), and H
419-3-3-7-16-4-1 (31); and the other consisting of the cultivars Catucaí Amarelo 2SL (4), Catucaiam 24137 (5), Catucaí 785-15 (7), Catucaí Vermelho 20/15 (8), IPR 100 (20), IPR 103 (21), and Oeiras MG 6851 (23).

Genetic distance between the cultivars Catuaí Vermelho IAC 144 (1), Catuaí Vermelho IAC 15 (2), and the progeny H 419-3-3-7-16-4-1 (31) was 0. This set of 16 selected SSR markers could not be distinguished among these cultivars. Similarly, it was not possible to distinguish between Catucaí Amarelo 2SL (4) and Catucaiam 24137 (5).

The dissimilarity obtained at the last fusion level was 0.41. Maximum dissimilarity (0.6563) was observed between the cultivars Catucaí Amarelo 2SL (4) and MGS Catiguá 3 (26). The same genetic distance was observed between the cultivars Catucaí 785-15 (7) and MGS Catiguá 3 (26).

A total of 31 distinct molecular profiles were obtained through fingerprinting analysis, which considered the genotyping data of the bulk of six
Fig. 1 Dendrogram obtained by the UPGMA technique, based on the dissimilarity matrix of the arithmetic complement of the unweighted index from 34 C. arabica cultivars/ progenies. The numbers in the dendrogram are related to the cultivars described in the Table

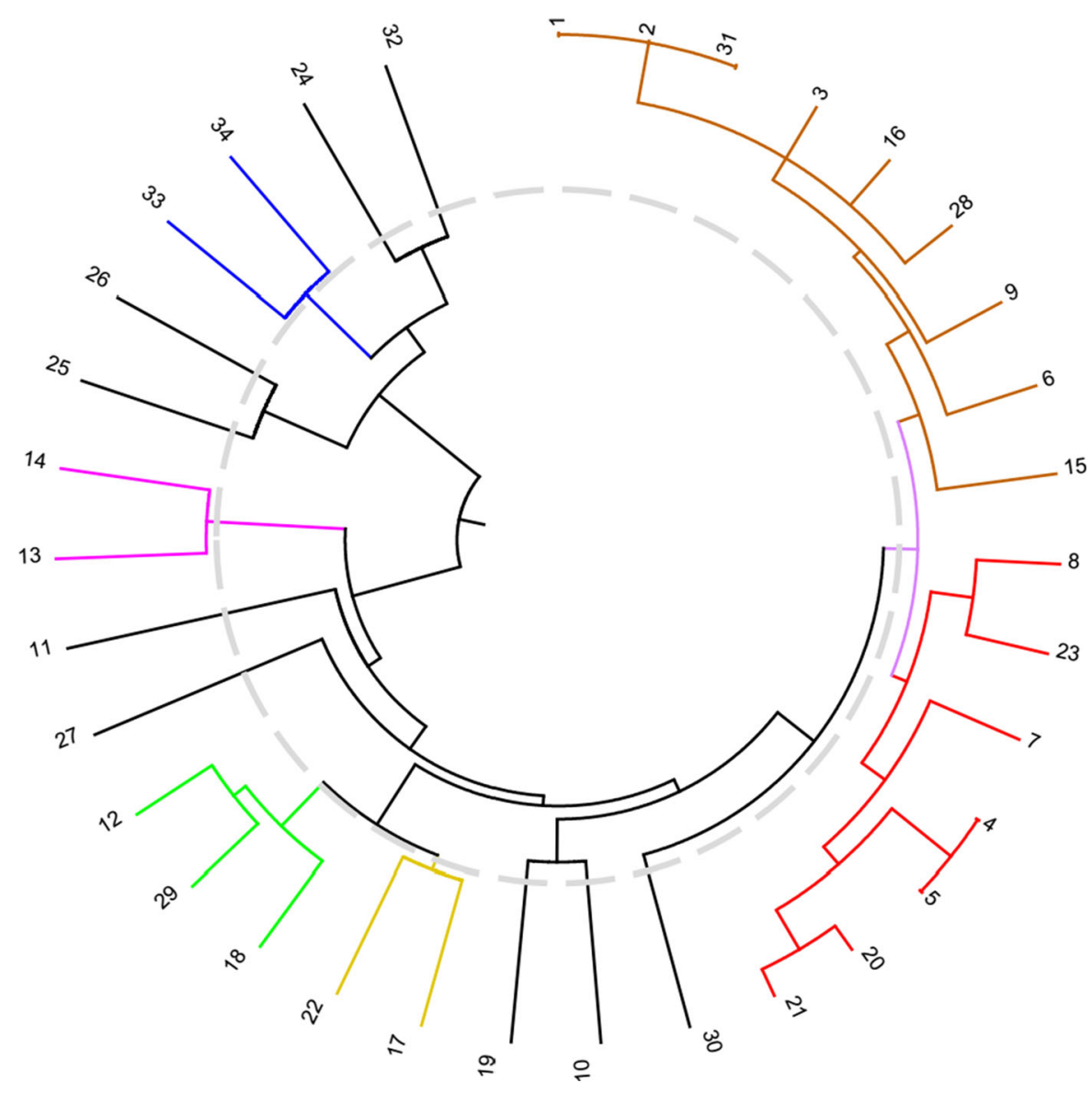


individuals of each cultivar/progeny (Table 3). To facilitate visualization and interpretation, each genotype received a distinct color, and genotypes 11, 22, and 33 were recoded as 1, 2 and 3, respectively. A unique molecular profile was obtained for cultivars Catuaí Vermelho IAC 144 (1), Catuaí Vermelho IAC 15 (2), and progeny H 419-3-3-7-16-4-1 (31). Thus, as in the dendrogram, these cultivars/progenies were not discriminated. The same occurred for Catucaí Amarelo 2SL (4) and Catucaiam 24137 (5).. (Color table online)

In the second fingerprinting analysis, molecular profiles of cultivars/progenies were obtained through the individual data of the genotypes that constitute them (Table 4). One to three different genotypes per cultivar/progeny were observed in each locus. All the different genotypes presented by a cultivar/progeny were taken into account for the construction of molecular profile. For instance, evaluation of CaEST-001 locus in Sacramento MG1 (27) cultivar revealed one plant with the allele $\left(\mathrm{A}^{1} \mathrm{~A}^{1}\right)$, the second with $\left(\mathrm{A}^{1} \mathrm{~A}^{2}\right)$, and the third with $\left(\mathrm{A}^{2} \mathrm{~A}^{2}\right)$. Therefore, Sacramento MG1 (27) cultivar profiles for CaEST-001 marker are 1, 12, and 2 (Table 4). This indicates that these three genotypes can be found in this cultivar.

\section{Discussion}

In 34 C. arabica cultivars, a mean of 2.35 alleles per primer was obtained using 20 polymorphic markers. Similar to this result, a mean of 2.5 alleles per microsatellite primer has been reported in a study on 19 C. arabica cultivars (Vieira et al. 2010); indicating a narrow genetic base between the cultivars/progenies. This can be explained by the low number of plants that were initially introduced in Brazil, which constitute the genetic base of the current cultivars (Setotaw et al. 2013). According to these authors, the genetic base of the 121 cultivars released in Brazil between 1939 and 2009 originated only from 13 parents. They also found that out of these parents, seven contributed to $97.55 \%$ of the genetic base of $C$. arabica cultivars from Brazil, the world's largest coffee producer.

A high percentage of polymorphic primers (74.04\%) was observed. However, most primers used in the analysis were selected for being polymorphic in other studies on this species (Capucho et al. 2009; Ferrão et al. 2015; Pestana et al. 2015), explaining the high polymorphism found in this study. In several studies, approximately $10 \%$ polymorphic SSR markers have been observed in $C$. arabica (Capucho et al. 2009; Pestana et al. 2015). In an $F_{2}$ population derived from the cross between Catuaí Amarelo IAC 64 (UFV 2148-57) and Híbrido de Timor UFV 443-03, 7.34\% polymorphism was observed in 286 SSR primers (Capucho et al. 2009). This same population analyzed by 373 pairs of microsatellite primers presented $15.5 \%$ polymorphic primers (Pestana et al. 2015). These results demonstrate the low genetic variability of this species, since the studied population originated from a contrasting cross in the $\mathrm{F}_{2}$ generation. In several studies, a small number of polymorphic loci was observed for C. arabica (Combes et al. 2000; Anthony et al. 2001; Anthony et al. 2002; Sera et al. 2003; Diniz et al. 2005; Vieira et al. 2010).

Another factor that influences the high genetic similarity between $C$. arabica cultivars analyzed in the present study was the parents used as sources of rustresistant genes. Coffee rust is considered the most important disease in coffee (Zambolim 2016); researchers use the same sources of rust-resistant genes worldwide. These parents are derived primarily from Híbrido de Timor, Icatu, and Indian Selections (Avelino et al. 2015). Cultivars/progenies carrying rust-resistant genes, which have been released and form part of the Cultivars National Trial, are derived from Híbrido de Timor and Icatu. The cultivar IPR 100 (20) is the only exception, whose parent used as a source of rust-resistant genotype was BA-10, an Indian selection.

The high genetic similarity between coffee cultivars highlights the need to identify a set of informative molecular markers that are able to differentiate among them and consequently be used for cultivar fingerprinting. Once identified, this set of markers will facilitate discrimination between cultivars in DUS testing.

The molecular profiles of the cultivars were obtained using 20 polymorphic markers. Four plants were eliminated because they showed different alleles in several loci. This indicated the possibility of varietal mixture. The mixture was confirmed by the phenotypic data in the field. The plant 32-B1-P6 (cultivar Catuaí Vermelho IAC 15 [2]) presented yellow fruits, differing from the fruit color standard of the cultivar. Genotype 16-B3-P1 (cultivar Tupi IAC 1669-33 [13]) was susceptible to rust, differing from the standard of 
Table 3 Molecular profile of 34 evaluated cultivars/progenies obtained by bulking of individuals that constitute the cultivars/ progenies of Coffea arabica. (Colour table online)

\section{Microsatellite markers}

\section{Cultivar/progeny}

CaEST

SSR

$\begin{array}{lllllllllllllllll}001 & 002 & 022 & 024 & 028 & 029 & 030 & 031 & 034 & 045 & 048 & 058 & 071 & 072 & 16 & 95\end{array}$

1 Catuaí Vermelho IAC 144

2 Catuaí Vermelho IAC 15

$\begin{array}{lllllll}2 & 3 & 2 & 12 & 2 & 2 & 12\end{array}$

3 Bourbon Amarelo UFV535

$\begin{array}{llllllllll}2 & 3 & 2 & 12 & 2 & 2 & 12 & 1 & 2 & 2\end{array}$

4 Catucaí Amarelo 2SL

5 Catucaiam 24137

$\begin{array}{llllllllllllll}2 & 3 & 2 & 12 & 2 & 2 & 12 & 1 & 2 & 2\end{array}$

6 Catucaiam 2015479

$\begin{array}{lllll}2 & 3 & 2 & 12 & 2\end{array}$

7 Catucaí 785-15

$\begin{array}{lllllllll}2 & 3 & 12 & 12 & 2 & 2 & 12 & 1 & 2\end{array}$

8 Catucaí Vermelho 20/15

$\begin{array}{llllllllll}2 & 3 & 2 & 12 & 12 & 2 & 12 & 12 & 2 & 2\end{array}$

9 Sabiá tardio

$\begin{array}{llllll}2 & 3 & 1 & 12 & 2 \\ 2 & 3 & 2 & 12 & 2\end{array}$

10 IBC-Palma-2

$\begin{array}{llllllllll}2 & 3 & 2 & 12 & 2 & 2 & 12 & 1 & 2 & 2\end{array}$

11 Acauã

$\begin{array}{lllll}2 & 2 & 2 & 12 & 12\end{array}$

12 Tupi Amarelo IAC 5162

13 Tupi IAC 1669-33

$\begin{array}{llllllllll}12 & 1 & 2 & 12 & 2 & 1 & 12 & 3 & 2 & 2\end{array}$

14 IAC 125 RN

\begin{tabular}{l|l|l|l|l}
2 & 23 & 2 & 12 & 2
\end{tabular}

15 Obatã IAC 1669-20

16 Obatã Amarelo 4932

17 Iapar 59

$\begin{array}{llllllllll}12 & 2 & 2 & 1 & 2 & 2 & 12 & 1 & 2 & 2\end{array}$

18 IPR 98

$\begin{array}{llllllllll}2 & 3 & 2 & 1 & 2 & 2 & 12 & 3 & 2 & 2\end{array}$

19 IPR 99

$\begin{array}{lllll}2 & 2 & 2 & 12\end{array}$

20 IPR 100

21 IPR 103

22 IPR 104

2

12

23 Oeiras MG 6851

\begin{tabular}{lllll}
2 & 23 & 2 & 12 & 2 \\
\hline
\end{tabular}

24 Catiguá MG1

\begin{tabular}{lllll}
2 & 2 & 2 & 12 & 1 \\
\hline
\end{tabular}

25 Catiguá MG2

$\begin{array}{llllllllll}2 & 3 & 2 & 12 & 2 & 2 & 12 & 2 & 2 & 2\end{array}$

26 MGS Catiguá 3

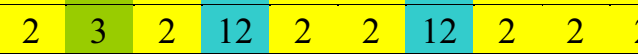

27 Sacramento MG1

$\begin{array}{llllllllll}12 & 3 & 2 & 12 & 2 & 1 & 12 & 3 & 2 & 2\end{array}$

28 Araponga MG1

29 Pau Brasil MG1

\begin{tabular}{lllll}
2 & 3 & 2 & 12 & 2 \\
\hline
\end{tabular}

$\begin{array}{cccccccccc}2 & 13 & 2 & 12 & 2 & 2 & 12 & 13 & 12 & 2 \\ 2 & 3 & 2 & 12 & 2 & 2 & 12 & 3 & 12 & 1\end{array}$

30 Paraíso MG H 419-1

$\begin{array}{lllllllll}2 & 3 & 2 & 12 & 2 & 2 & 12 & 3 & 1\end{array}$

31 H 419-3-3-7-16-4-1

$\begin{array}{llllllllll}12 & 13 & 2 & 12 & 12 & 2 & 12 & 13 & 1 & 2\end{array}$

32 H 419-10-6-2-5-1

2

33 H 419-10-6-2-10-1

34 H 419-10-6-2-12-1

$\begin{array}{ccccccccccc}2 & 23 & 2 & 12 & 2 & 2 & 12 & 1 & 2 & 2 \\ 2 & 23 & 2 & 12 & 2 & 12 & 12 & 13 & 12 & 2\end{array}$

$1=\mathrm{A}^{1} \mathrm{~A}^{1} ; 2=\mathrm{A}^{2} \mathrm{~A}^{2} ; 3=\mathrm{A}^{3} \mathrm{~A}^{3} ; 12=\mathrm{A}^{1} \mathrm{~A}^{2} ; 13=\mathrm{A}^{1} \mathrm{~A}^{3} ; 23=\mathrm{A}^{2} \mathrm{~A}^{3}$ 


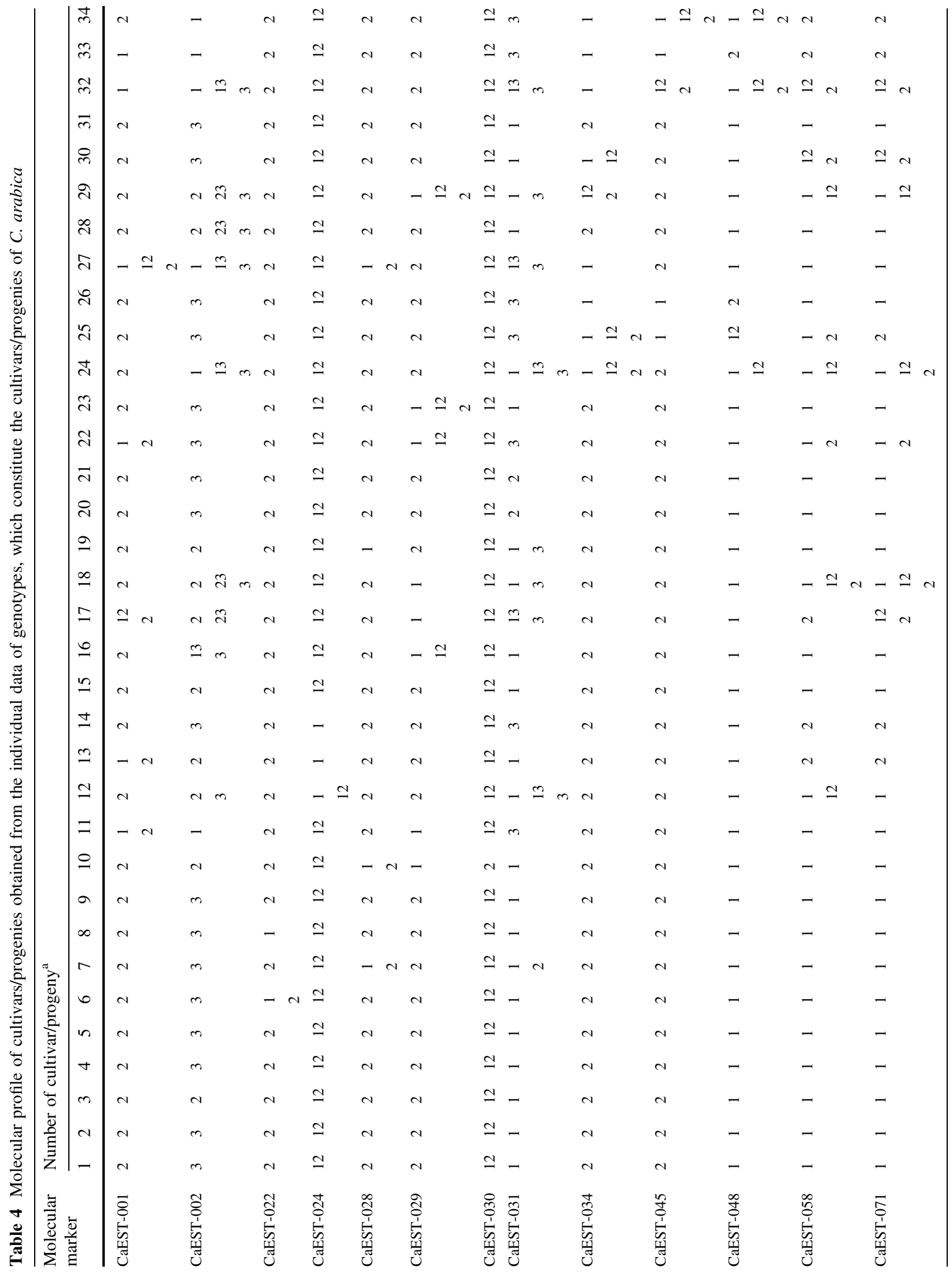




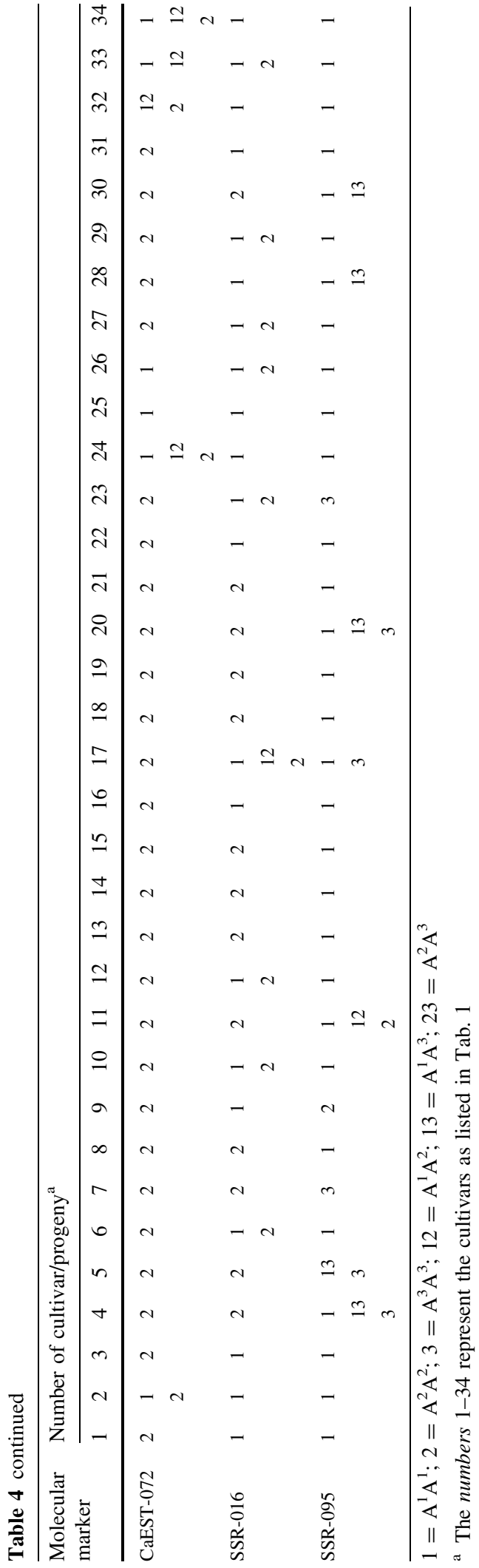

the cultivar which harbors resistant genes. The plant 30-B2-P4 (cultivar IAC $125 \mathrm{RN}$ [14]) was more vigorous than other plants of this cultivar. These results demonstrate the ability of the marker to detect mixtures; therefore, in further studies and in the absence of field data, markers should be used to eliminate varietal mixtures.

Segregation between and within cultivars/progenies was observed by molecular analysis of the markers used in this study. The existence of genetic variation between the majority of cultivars demonstrated the effectiveness of SSR markers to differentiate cultivars of species with narrow and phenotypically similar genetic base.

Segregation in $C$. arabica cultivars can be explained by ploidy (tetraploid); although this species is self-pollinated, it presents approximately $10 \%$ outcrossing (Lashermes et al. 2000). Thus, greater number of selfing generations is required to increase the level of homozygosity. In addition, this species is perennial with a long juvenile period, a fact that extends the advancement of generations (Sera 2001). However, for the viability of breeding programs and to release new cultivars, plant breeders register $C$. arabica cultivars that can segregate even when they are in $\mathrm{F}_{6}$ or more advanced generations. The occurrence of late segregations was observed in progenies in which no phenotypic segregations were found in earlier generations.

Analysis of the 20 polymorphic markers revealed that the number of polymorphic loci within each cultivar/progeny ranged from 0 to 11 . Eight cultivars/ progenies did not segregate among the six individuals which constitute them, suggesting high level of homozygosity. In cultivar Catiguá MG1 (24), polymorphism was observed in 11 loci (55\%). Cultivar Catiguá MG1 (24) originated from an artificial cross between cultivar Catuaí Amarelo IAC 86 and Híbrido de Timor UFV 440-10, which were susceptible and resistant to rust, respectively. These parents are genetically divergent, which explains the genetic variation observed in the cultivar. Furthermore, this cultivar was released in the $F_{5}$ generation; in this generation, relatively high levels of heterozygosity are commonly observed in polyploid species.

Of the 20 polymorphic SSR markers evaluated, four were eliminated for being tetraploid. This is due to the probable origin of $C$. arabica. It is believed that this species originated from the fusion of unreduced 
gametes of the diploid species $C$. eugenioides and $C$. canephora (Lashermes et al. 1999). The genomes of these species have high similarity, and there may be duplicated regions in C. arabica genome. The SSR marker located in the duplicated regions, present in the genome of the two-parent species of $C$. arabica, have four alleles per individual (tetraploid). The SSR markers of non-duplicated regions presented two alleles per individual (diploid). The exclusion of tetraploid molecular markers occurred in order to take advantage of the codominant nature of the marker. Therefore, all subsequent analyses were performed with 16 SSR that performed as diploid and codominant molecular markers.

The molecular markers CaEST024 and CaEST030 presented a heterozygous molecular pattern for most cultivars/progenies evaluated. This would not be expected since $C$. arabica is an autogamous species. However, this may be justified by the fact that the molecular marker amplifies the alleles in homeologous chromosomes of the two genomes that comprise this species. Thus, in each homologous chromosome, the alleles are homozygous and, with the self-fertilization cycles, no genetic variation is expected by the meiotic process. In polyploid crops, genome duplication results in a considerable number of duplicated genes or homeologs. Duplicated genes or homeologs may be differentially expressed depending on the organ, developmental stage, and environment, which increase the difficulty in discriminating the function of individual genes. In addition, numerous duplicated genes or homeologs and repetitive sequences hinder the correct sequence assembly and the accurate quantification of gene expression (Fu et al. 2016).

Dendrogram analysis showed 14 groups. Cultivars Iapar 59 (17) and IPR 104 (22) were allocated in the same group. These cultivars were developed by breeding program of the Instituto Agronômico do Paraná (IAPAR), and both are derived from Sarchimor (Villa Sarchi $\times$ Híbrido de Timor CIFC 832/2). The other two groups were also allocated materials of the same breeding institution. One group with cultivars Tupi IAC 1669-33 (13) and IAC 125 RN (14) belongs to Instituto Agronômico de Campinas (IAC) and the other group with progenies H 419-10-6-2-10-1 (33) and $\mathrm{H}$ 419-10-6-2-12-1 (34) originated from Empresa de Pesquisa Agropecuária de Minas Gerais (EPAMIG) and Universidade Federal de Viçosa (UFV). Cultivars Tupi IAC 1669-33 (13) and IAC 125 RN (14) were selected from seeds of the same hybrid (CIFC H361/ 4). The same occurred with the progenies $\mathrm{H}$ 419-10-62-10-1 (33) and H 419-10-6-2-12-1 (34), which were selected from the cross between Catuaí Amarelo IAC 30 and Híbrido de Timor UFV 445-4. This justifies the allotment of the genotypes to the same group.

Cultivars Tupi Amarelo IAC 5162 (12), IPR 98 (18), and Pau Brasil MG1 (29) constitute a single group. The other cultivars were allocated to another group that can be subdivided into two subgroups. In the first subgroup, the cultivars Catuaí Vermelho IAC 144 (1), Catuaí Vermelho IAC 15 (2), and the progeny Bourbon Amarelo UFV 535 (3) are susceptible to coffee rust (Patricio et al. 2010). In addition, the first two cultivars belong to the Catuaí group, justifying the high similarity between them. The other cultivars in this first subgroup carry rust-resistant factors and present the cultivar Catuaí Amarelo in their genetic constitutions.

All cultivars allocated in the second subgroup are moderately resistant to coffee rust. This subgroup allocated the cultivars that have Icatu as source of resistance factors, except for cultivar Catucaiam 2015479 (6), which was allocated to the first subgroup.

Similarity was observed between the cultivars Catuaí Vermelho IAC 144 (1), Catuaí Vermelho IAC 15 (2), and the progeny $\mathrm{H}$ 419-3-3-7-16-4-1 (31). Similarity between the cultivars Catuaí Vermelho IAC 144 (1) and Catuaí Vermelho IAC 15 (2) can be explained by their genealogy, since they are derived from the genotype $\mathrm{H}$ 2077-2. Phenotypic traits of progeny H 419-3-3-7-16-4-1 (31) demonstrate its genetic proximity to cultivar Catuaí, corroborating the high similarity found between these materials in the present study.

Genetic distance between the cultivars Catucaí Amarelo 2SL (4) and Catucaiam 24137 (5) was also 0. Cultivars of the Catucaí group are derived from natural cross between germplasm Icatu and Catuaí, which is a possible reason for the high similarity observed. Moreover, these cultivars have high phenotypic similarity.

Maximum dissimilarity (0.656) obtained between cultivars Catucaí Amarelo 2SL (4) and MGS Catiguá 3 (26), and between cultivars Catucaí 785-15 (7) and MGS Catiguá 3 (26), may be because of the parents used as a source of rust resistance. In Catucaí cultivars, one of the parents was Icatu; in contrast, in cultivar MGS Catiguá 3 (26), the parent used as source of rust resistance was Híbrido de Timor. 
Fingerprinting analysis with the bulk of data of the individuals that compose each cultivar/progeny revealed 31 unique molecular profiles. This result is very important to distinguish these materials. Besides presenting narrow genetic base, these materials are phenotypically similar. Application of SSR molecular markers in fingerprinting analysis, together with genetic diversity, has been reported in several plant species (Barchi et al. 2011; Triwitayakorn et al. 2011; Hajibarat et al. 2015; Chen et al. 2016; Rayda et al. 2016; Maldonado Dos Santos et al. 2016). These authors have highlighted the importance of using molecular markers. In sugarcane, with three SSR markers, 1,205 genotypes (Maccheroni et al. 2009) were differentiated. Seven microsatellite polymorphic markers were used to analyze paternity in seven parent sugarcane polycrosses (Tew and Pan 2010). SSR molecular markers have proved to be accurate in the discrimination of cultivar/progenies (Dutta et al. 2011). With the use of SSR markers, 128 Camellia sinensis cultivars were correctly discriminated (Tan et al. 2015).

Once genetic variation is detected between individuals of the same cultivar, analysis of the molecular profile based on bulk data may mislead the detection of some genotypes belonging to the cultivar. Therefore, in the present study, the molecular profile was also made available with all genotypic possibilities, considering allelic variations of the cultivar (Table 4).

The unique molecular profile of a cultivar will facilitate distinguishing kinship genotypes from those with similar phenotypic traits. Thus, fingerprinting is an auxiliary tool to the recommended descriptors, being extremely useful in DUS tests required for the registration process and for plant variety protection.

Acknowledgements This work was financially supported by the Brazilian Coffee Research and Development Consortium (Consórcio Brasileiro de Pesquisa e Desenvolvimento do Café CBP\&D/Café), by the Foundation for Research Aid of the State of Minas Gerais (FAPEMIG); by the National Council of Scientific and Technological Development (CNPq), and by the National Institutes of Science and Technology of Coffee (INCT/ Café).

\section{Compliance with Ethical Standards}

Conflict of interest The authors declare no conflict of interest.

Data archiving statement The authors have not submitted biological data to any of the public databases.

\section{References}

Anthony F, Bertrand B, Quiros O et al (2001) Genetic diversity of wild coffee (Coffea arabica L.) using molecular markers. Euphytica 118:53-65. doi:10.1023/A:1004013815166

Anthony F, Combes C, Astorga C et al (2002) The origin of cultivated Coffea arabica L. varieties revealed by AFLP and SSR markers. Theor Appl Genet 104:894-900. doi:10. 1007/s00122-001-0798-8

Avelino J, Cristancho M, Georgiou S et al (2015) The coffee rust crises in Colombia and Central America (2008-2013): impacts, plausible causes and proposed solutions. Food Secur 7:303-321. doi:10.1007/s12571-015-0446-9

Banerjee S, Das M, Mir R et al (2012) Assessment of genetic diversity and population structure in a selected germplasm collection of 292 jute genotypes by microsatellite (SSR) markers. Mol Plant Breed 3:11-25. doi:10.5376/mpb. 2012. 03.0002

Barchi L, Lanteri S, Portis E et al (2011) Identification of SNP and SSR markers in eggplant using RAD tag sequencing. BMC Genom 12:304. doi:10.1186/1471-2164-12-304

Brasil (2017a) Ministério da Agricultura, Pecuária e Abastecimento. In: Regist. Nac. Cultiv. - RNC. http://extranet. agricultura.gov.br/php/snpc/cultivarweb/cultivares_registr adas.php. Accessed 9 Feb 2017

Brasil (2017b) CULTIVARWEB GERENCIAMENTO DE INFORMAÇÃO. In: SERVIÇO Nac. PROTEÇÃO Cultiv. - SNPC. http://extranet.agricultura.gov.br/php/snpc/ cultivarweb/cultivares_protegidas.php. Accessed 9 Feb 2017

Brito GG, Caixeta ET, Gallina AP et al (2010) Inheritance of coffee leaf rust resistance and identification of AFLP markers linked to the resistance gene. Euphytica 173:255-264. doi:10.1007/s10681-010-0119-x

Capucho AS, Caixeta ET, Zambolim EM, Zambolim L (2009) Herança da resistência do Híbrido de Timor UFV 443-03 à ferrugem-do-cafeeiro. Pesqui Agropecuária Bras 44:276-282. doi:10.1590/S0100-204X2009000300009

Carvalho A (1981) Novas variedades mais produtivas. Agric Hoje 6:32-34

Chen Y, Dai X, Hou J et al (2016) DNA fingerprinting of oil camellia cultivars with SSR markers. Tree Genet Genomes 12:7. doi:10.1007/s11295-015-0966-7

Collard BCY, Jahufer MZZ, Brouwer JB, Pang ECK (2005) An introduction to markers, quantitative trait loci (QTL) mapping and marker-assisted selection for crop improvement: the basic concepts. Euphytica 142:169-196. doi:10. 1007/s10681-005-1681-5

Combes MC, Andrzejewski S, Anthony F et al (2000) Characterization of microsatellite loci in Coffea arabica and related coffee species. Mol Ecol 9:1178-1180. doi:10. 1046/j.1365-294x.2000.00954-5.x

Cruz CD (2013) GENES - a software package for analysis in experimental statistics and quantitative genetics. Acta Sci Agron 35:271-276. doi:10.4025/actasciagron.v35i3.21251

Cruz CD, Ferreira FM, Pessoni LA (2011) Biometria aplicada ao estudo da diversidade genética. Suprema, Visconde do Rio Branco

Cubry P, Musoli P, Legnate H et al (2008) Diversity in coffee assessed with SSR markers: structure of the genus Coffea 
and perspectives for breeding. Genome 51:50-63. doi:10. 1139/G07-096

de Carvalho SI, de Bianchetti LB, Reifschneider FJ (2009) Registro e proteção de cultivares pelo setor público: a experiência do programa de melhoramento de Capsicum da Embrapa Hortaliças. Hortic Bras 27:135-138. doi:10.1590/ S0102-05362009000200002

Diniz LEC, Sakiyama NS, Lashermes P et al (2005) Analysis of AFLP markers associated to the Mex-1 resistance locus in Icatu progenies. Crop Breed Appl Biotechnol 5:387-393. doi:10.12702/1984-7033.v05n04a03

Diola V, de Brito GG, Caixeta ET et al (2011) High-density genetic mapping for coffee leaf rust resistance. Tree Genet Genomes 7:1199-1208. doi:10.1007/s11295-011-0406-2

Dutta S, Kumawat G, Singh BP et al (2011) Development of genic-SSR markers by deep transcriptome sequencing in pigeonpea [Cajanus cajan (L.) Millspaugh]. BMC Plant Biol 11:11-17. doi:10.1186/1471-2229-11-17

Ercisli S, Orhan E, Esitken A et al (2008) Relationships among some cornelian cherry genotypes (Cornus mas L.) based on RAPD analysis. Genet Resour Crop Evol 55:613-618. doi:10.1007/s10722-007-9266-X

Ercisli S, Ipek A, Barut E (2011) SSR marker-based DNA fingerprinting and cultivar identification of olives (Olea europaea). Biochem Genet 49:555-561. doi:10.1007/ s10528-011-9430-z

Fernandes ALT, Partelli FL, Bonomo R, Golynski A (2012) A moderna cafeicultura dos cerrados brasileiros. Pesqui Agropecuária Trop 42:231-240. doi:10.1590/S198340632012000200015

Ferrão LFV, Caixeta ET, Pena G et al (2015) New EST-SSR markers of Coffea arabica: transferability and application to studies of molecular characterization and genetic mapping. Mol Breed 35:31. doi:10.1007/s11032-015-0247-z

Ferreira AD, Carvalho GR, de Rezende JC et al (2013) Desempenho agronômico de seleções de café Bourbon Vermelho e Bourbon Amarelo de diferentes origens. Pesqui Agropecuária Bras 48:388-394. doi:10.1590/S0100204X2013000400006

Ferreira V, Ramos-Cabrer AM, Carnide V et al (2016) Genetic pool structure of local apple cultivars from Portugal assessed by microsatellites. Tree Genet Genomes 12:36. doi:10.1007/s11295-016-0997-8

Fu D, Mason AS, Xiao M, Yan H (2016) Effects of genome structure variation, homeologous genes and repetitive DNA on polyploid crop research in the age of genomics. Plant Sci 242:37-46. doi:10.1016/j.plantsci.2015.09.017

Hajibarat Z, Saidi A, Hajibarat Z, Talebi R (2015) Characterization of genetic diversity in chickpea using SSR markers, start codon targeted polymorphism (SCoT) and conserved DNA-derived polymorphism (CDDP). Physiol Mol Biol Plants 21:365-373. doi:10.1007/s12298-015-0306-2

Kaur S, Panesar PS, Bera MB, Kaur V (2015) Simple sequence repeat markers in genetic divergence and marker-Assisted selection of rice cultivars: a review. Crit Rev Food Sci Nutr 55:41-49. doi:10.1080/10408398.2011.646363

Korir NK, Han J, Shangguan LF et al (2013) Plant variety and cultivar identification: advances and prospects. Crit Rev Biotechnol 33:111-125. doi:10.3109/07388551.2012.675314

Kumar S, Stecher G, Tamura K (2016) MEGA7: molecular evolutionary genetics analysis version 7.0 for bigger datasets. Mol Biol Evol 33:1870-1874. doi:10.1093/ molbev/msw054

Lanteri S, Portis E, Acquadro A et al (2012) Morphology and SSR fingerprinting of newly developed Cynara cardunculus genotypes exploitable as ornamentals. Euphytica 184:311-321. doi:10.1007/s10681-011-0509-8

Lashermes P, Combes M-C, Robert J et al (1999) Molecular characterisation and origin of the Coffea arabica L. genome. Mol Gen Genet MGG 261:259-266. doi:10.1007/ s004380050965

Lashermes P, Andrzejewski S, Bertrand B et al (2000) Molecular analysis of introgressive breeding in coffee (Coffea arabica L.). TAG Theor Appl Genet 100:139-146. doi:10. 1007/s001220050019

Lashermes P, Combes MC, Ansaldi C et al (2011) Analysis of alien introgression in coffee tree (Coffea arabica L.). Mol Breed 27:223-232. doi:10.1007/s11032-010-9424-2

Le S, Ratnam W, Harwood CE (2016) A multiplexed set of microsatellite markers for discriminating Acacia mangium, A. auriculiformis, and their hybrid. Tree Genet Genomes 21:31. doi:10.1007/s11295-016-0990-2

Maccheroni W, Jordao H, de Gaspari R et al (2009) Development of a dependable microsatellite-based fingerprinting system for sugarcane. Sugar Cane Intl 27:47-52

Maldonado Dos Santos JV, Valliyodan B, Joshi T et al (2016) Evaluation of genetic variation among Brazilian soybean cultivars through genome resequencing. BMC Genom 17:110. doi:10.1186/s12864-016-2431-x

Maluf MP, Silvestrini M, de Ruggiero LMC et al (2005) Genetic diversity of cultivated Coffea arabica inbred lines assessed by RAPD, AFLP and SSR marker systems. Sci Agric 62:366-373. doi:10.1590/S0103-90162005000400010

Missio RF, Caixeta ET, Zambolim EM et al (2011) Genetic characterization of an elite coffee germplasm assessed by gSSR and EST-SSR markers. Genet Mol Res 10:2366-2381. doi:10.4238/2011.October.6.2

Motta LB, Soares TCB, Ferrao MAG et al (2014) Molecular characterization of arabica and conilon coffee plants genotypes by SSR and ISSR markers. Braz Arch Biol Technol 57:728-735. doi:10.1590/S1516-8913201402071

Patricio FRA, Braghini MT, Fazuoli LC (2010) Resistência de plantas de Coffea arabica, coffea canephora e híbridos interespecíficos à cercosporiose. Bragantia 69:883-890. doi:10.1590/S0006-87052010000400014

Pestana KN, Capucho AS, Caixeta ET et al (2015) Inheritance study and linkage mapping of resistance loci to Hemileia vastatrix in Híbrido de Timor UFV 443-03. Tree Genet Genomes 11:72. doi:10.1007/s11295-015-0903-9

Rauscher G, Simko I (2013) Development of genomic SSR markers for fingerprinting lettuce (Lactuca sativa L.) cultivars and mapping genes. BMC Plant Biol 13:11. doi:10. 1186/1471-2229-13-11

Rayda BA, Hanen BH, Karim E, Ahmed R (2016) Genetic markers analyses and bioinformatic approaches to distinguish between olive tree (Olea europaea L.) Cultivars. Interdiscip Sci Comput Life. doi:10.1007/s12539-0160155-x

Santos FS, de Aviani DM, Hidalgo JAF et al (2012) Evolution, importance and evaluation of cultivar protection in Brazil: the work of the SNPC. Crop Breed Appl Biotechnol 12:99-110. doi:10.1590/S1984-70332012000500011 
Scarano D, Rao R, Masi P, Corrado G (2015) SSR fingerprint reveals mislabeling in commercial processed tomato products. Food Control 51:397-401. doi:10.1016/j. foodcont.2014.12.006

Sera T (2001) Coffee genetic breeding at IAPAR. Crop Breed Appl Biotechnol 1:179-199. doi:10.13082/1984-7033. v01n02a08

Sera T, Ruas PM, de Ruas CF et al (2003) Genetic polymorphism among 14 elite Coffea arabica L. cultivars using RAPD markers associated with restriction digestion. Genet Mol Biol 26:59-64. doi:10.1590/S1415-475720030001 00010

Setotaw TA, Caixeta ET, Pereira AA et al (2013) Coefficient of parentage in Coffea arabica L cultivars grown in Brazil. Crop Sci 53:1237-1247. doi:10.2135/cropsci2012.09.0541

Silvestrini M, Junqueira MG, Favarin AC et al (2007) Genetic diversity and structure of Ethiopian, Yemen and Brazilian Coffea arabica L. accessions using microsatellites markers. Genet Resour Crop Evol 54:1367-1379. doi:10.1007/ s10722-006-9122-4

Tan L-Q, Peng M, Xu L-Y et al (2015) Fingerprinting 128 Chinese clonal tea cultivars using SSR markers provides new insights into their pedigree relationships. Tree Genet Genomes 11:90. doi:10.1007/s11295-015-0914-6
Tew TL, Pan Y-B (2010) Microsatellite (simple sequence repeat) marker-based paternity analysis of a seven-parent sugarcane polycross. Crop Sci 50:1401-1408. doi:10.2135/ cropsci2009.10.0579

Triwitayakorn K, Chatkulkawin P, Kanjanawattanawong S et al (2011) Transcriptome sequencing of Hevea brasiliensis for development of microsatellite markers and construction of a genetic linkage map. DNA Res 18:471-482. doi:10.1093/ dnares/dsr034

UPOV (2010) Guidelines for DNA profiling: molecular marker selection and database construction (BMT guidelines). Switzerland, Geneva

Vieira ESN, Von Pinho ÉVDR, Carvalho MGG et al (2010) Development of microsatellite markers for identifying Brazilian Coffea arabica varieties. Genet Mol Biol 33:507-514. doi:10.1590/S1415-47572010005000055

Wang J-Y, Chuang K-C (2013) Development of novel microsatellite markers for effective applications in Anthurium cultivar identification. Euphytica 189:421-431. doi:10.1007/s10681-012-0799-5

Zambolim L (2016) Current status and management of coffee leaf rust in Brazil. Trop Plant Pathol 41:1-8. doi:10.1007/ s40858-016-0065-9 